\title{
A Comparison of the Act and Frequency of Plagiarism between Technical and Non-Technical Programme Undergraduates
}

\author{
Madhubala BavaHarji ${ }^{1}$, Thiba Naraina Chetty ${ }^{1}$, Zalina Bt Ismail ${ }^{1} \&$ Krishnaveni Letchumanan ${ }^{1}$ \\ ${ }^{1}$ Learning Institute for Empowerment (LIFE), Multimedia University, Malaysia \\ Correspondence: Krishnaveni Letchumanan, (LIFE), Multimedia University, FCM Building 3rd Floor, Persiaran \\ Multimedia, 63100 Cyberjaya, Selangor Darul Ehsan, Malaysia. Tel: 603-8312-5757. E-mail: \\ veni26571@gmail.com
}

Received: January 13, 2016 Accepted: March 5, 2016 Online Published: March 8, 2016

doi: 10.5539/elt.v9n4p106 URL: http://dx.doi.org/10.5539/elt.v9n4p106

\begin{abstract}
Concerned with intellectual theft, we decided to examine intellectual theft among undergraduates at a higher education institution. The aim of this study was to compare the act and frequency of plagiarism, particularly between programmes, gender, year of study and academic performance. This study adopted the quantitative approach, using a questionnaire to gather the students' background information and the general practice of intellectual theft. It was administered to 120 students. For the purpose of this study, we categorised the programmes into Technical programme (TP) and Non-Technical programme (NTP). This study found that the act of plagarising was prevalent in both categories of the programmes, however, more prevalent among the technical programme students than the non-technical programme students. We also found that the act of intellectual theft was more evident among the males than female, junior than seniors and average academic achievers than high achievers. A comparison between programmes found significant differences in the act of plagiarism among gender, particularly among the female NTP students, among the Year 3 students and among the high achievers. No significant difference was found in relation to the frequency of plagiarism between programmes and gender, but among the students who sometimes plagiarise by level of study and by academic achievements.
\end{abstract}

Keywords: academic performance, intellectual theft, non-technical, plagiarism, seniority, technical, undergraduates, unethical behavior

\section{Introduction}

Plagiarism is not a new term currently trending. It goes way back to 1732 when Benjamin Franklin in his Poor Richard's Almanac, stole the literary ideas of Jonathan Swift in the latter's Bickerstaff Papers, which was written in 1708 and 1709. Many writers of the era did not see anything wrong with stealing ideas from others. It was only on April 10, 1710 that the world's first Copyright Act, known as the Statute of Anne, was passed in London. This Act, however, only provided protection for publishers, but not authors. It was later ratified at the Berne Convention, Switzerland in 1886, by Britain in 1887, and later by the USA in 1989.

With this Act, many researchers began examining, among others, the perceptions, attitudes, behaviour and reasons for plagiarism. The act of plagiarism or academic dishonesty was found to be prevalent among many university students (Bisping et al., 2008; Brown, Weible, \& Olmosk, 2010; Caron, Whitbourne, \& Halgin, 1992; McCabe \& Treviño, 1997; McCullough \& Holmberg, 2005; Smith et al., 2002; Paldy, 1996; Stebelman, 1998; Wilson, 1999). Various determinants, including academic pachievement, academic major, gender and seniority were also examined. Firstly, weaker academic performers, who may gain more from plagiarism (Bisping et al., 2008) were found to plagiarise more frequently compared to students with better academic grades (Bisping et al., 2008; McCabe \& Treviño, 1997; Smith et al., 2002). According to Mc Cabe and Treviño (1997) explained that higher achievers were found to be less likely to plagiarise as they have less to gain and more to lose. Secondly, students' act of plagiarism was found to be associated with their academic majors. Students in the technical majors were found to plagiarise more frequently than those in non-technical majors (Harding et al., 2001; McCullough \& Holmberg, 2005; Newstead et al., 1996, other studies, however, presented contrary results. Harris (1989), Caruana et al. (2000), Park (2003), Smyth and Davis (2004) and Brown, Weible and Olmosk (2010) found that business major [non-technical] students were more likely to plagiarise compared to those in non-business majors [technical]. Another determinant was gender. While most studies found that female students were constantly, albeit, not 
consistently less involved in the act of plagiarism than to male students (Hendershott, Drinan, \& Cross, 1999; McCabe \& Treviño, 1997; Rocha \& Teixeira, 2005a; Straw, 2002; Simon et al., 2004; Ward \& Beck, 2001; Yang, 2014), other studies found that female students were more likely to plagiarise (Taylor Bianco \& Deeter Schmelz, 2007; Mirshekary and Lawrence (2009). Roig and Caso (2005) and Bilic-Zulle, et al. (2005), on the other hand, found that plagiarism rate is not significantly affected by gender. Another equally pertinent determinant was academic seniority. Studies reported that while juniors tend to plagiarise more often (Baird, 1980; Bushway \& Nash, 1977; Haines et al., 1986; Smyth, Davis, \& Kroncke, 2009; Rocha \&Teixeira, 2005b), seniors were less likely to plagiarise (Deckert, 1993; Mc Cabe \& Trevino, 1997; McCabe, Trevino \& Butterfield, 2001; Rinnert \& Kobayashi, 2005; Sims, 1995; Smith et al., 2002). In general, the studies reviewed appeared to predominately examine one or two determinants, and therefore this study will examine all four of the above mentioned determinants, i.e. programme, gender, level of study and academic achievement.

With the advent of the internet, which only appears to exacerbate the act of plagiarising (Burton, Talpade \& Haynes, 2011; Groark, Oblinger, \& Choa, 2001; Lehman \& DuFrene, 2011; Oliphant, 2002; Thompson, 2003), it is not surprising to find that plagiarism continues to prevail in higher academic institutions (Carroll, 2002; McCabe \& Trevino, 1997; Park, 2003). Faculty members, management team and stakeholders are gravely concerned with the moral fibre of students who will be future leaders or captains of industries. A Google search showed that, albeit researched extensively in the 80 s to date, as noted by Lin and Wen (2007), it appears to be extensively researched in various countries, such as USA, UK, Canada, New Zealand, Japan etc, there appears to be limited studies that examined the act of plagiarism among student in the higher academic institution in the Malaysian context. While Iberahim et al. (2013) examined students' reasons for plagiarism, Smith et al. (2007) examined students' perception of contributing factors to plagiarism as well as relationships with students' characteristics and Ting (2013) studied students' behaviour and attitudes towards plagiarism. Mohd (2013) on the other hand, examined the final year students' views on various components of academic dishonesty, i.e. cheating on tests, cheating on assignments and plagiarism. Iberahim et al. (2013) found that students plagiarised because there appeared to be lack of instructors' control, the irrelevancy of assignments/ materials to subject and external, i.e. peer pressure pressure. Hence, it is not surprising that Ting (2013) found that students did not treat the act of plagiarism seriously as reflected in their preference for lighter penalties, if caught plagiarising. Mohd (2013) found female students cheated and plagiarised less often than males. Smith (2007) reported similar findings of the act of plagiarism being associated with male students who are weaker academically and who are less positive towards their studies. Apart from these studies, there appear to be no studies that examine the act of plagiarism by students in the different programmes, specifically, technical and non-technical programmes as well as students of different gender, levels of study, and level of academic achievement in Malaysia. Research has shown that dishonesty in colleges is a predictor of unethical behaviour in subsequent professional settings (Sierles, Hendrickx, \& Circle, 1980). Hence, the need for continuous research is evident to examine the extent of plagiarism among undergraduates and subsequently create awareness and empower academicians and educational institutions to address this concern.

\section{Research aims and questions}

The aim of this research was to compare the Technical Programme (TP) and Non-Technical Programme (NTP) students' act of plagiarism, i.e. whether they plagiarise or otherwise and if they plagiarise, what is the frequency or how often do they plagiarism. Thus the following research questions were addressed:

1) Is there a significant difference between the Technical and Non-Technical programme students' act of plagiarism and frequency of plagiarism?

2) Is there a significant difference between male and female students' act of plagiarism and frequency of plagiarism by programme?

3) Is there a significant difference in the act of plagiarism and frequency of plagiarism among students in the different levels of study by programme?

4) Is there a significant difference in the act of plagiarism and frequency of plagiarism among students of different academic achievement by programme?

\section{Method}

This study adopted the quantitative approach, using a questionnaire to gather background information of the students as well as their act of plagiarism, i.e. if they generally plagiarise or otherwise (a 'Yes' no 'Question') during their course of study. The questionnaire also included a question that required students who reported they plagiarise to indicate their frequency of plagiarism, i.e. to specify if the 'always, sometimes, seldom' plagiarise. 
It was administered to students undertaking both the Technical Programme (TP) (science) and Non-Technical (NTP) (non science discipline) programmes. The 120 participants were made up of 30 students from each programme who are at varying levels of study their respective programmes. The largest proportion of students are in Year 3 ( 58 students), followed by Year 1 (38 students), Year 2 (19 students) and Year 4 (5 students). Male students out-numbered female students in the TP and vice versa in the NTP. Except for the one student who recorded a low GPA of $<1.99$, the remaining students are within the average GPA of 2.0-2.99 (TP: 50\% students students; NTP: $40 \%$ students) and higher GPA of 3.0-4.0 (TP: 48.3\% students; NTP: $60 \%$ students) GPA levels. A summary of the participants' background information is presented in Table 1.

Table 1. Background information of participants

\begin{tabular}{llll}
\hline & & Technical Programme & $\begin{array}{l}\text { Non-Technical Programme } \\
\text { No }(\%)\end{array}$ \\
\hline \multirow{2}{*}{ Number of students } & $60(50.0)$ & $60(50.0)$ \\
Gender & Male $(n=60)$ & $34(56.7)$ & $26(43.3)$ \\
& Female $(n=60)$ & $26(43.3)$ & $34(56.7)$ \\
\multirow{4}{*}{ Level of study } & Year 1 $(n=38)$ & $30(50.0)$ & $8(13.3)$ \\
& Year 2 $(n=19)$ & $0(0.0)$ & $19(31.7)$ \\
& Year 3 $(n=58)$ & $27(45.0)$ & $31(51.7)$ \\
Academic & Year 4 $(n=5)$ & $3(5.0)$ & $2(3.3)$ \\
achievement & $<1.99(n=1)$ & $1(1.7)$ & $0(0.0)$ \\
(GPA) & $2.0-2.49(n=19)$ & $16(26.7)$ & $3(5.0)$ \\
& $2.5-2.99(n=35)$ & $14(23.3)$ & $21(35.0)$ \\
& $3.0-3.49(n=45)$ & $21(35.0)$ & $24(40.0)$ \\
\hline
\end{tabular}

\section{Results}

Data gathered was analysed using the SPSS software and the results are presented in the form of both, descriptive and inferential statistics, with the significant threshold set at 0.05 . The results are presented in answer to the research questions, i.e. firstly, the results for all 120 students, followed by the TP and NTP students' act of plagiarism and frequency of plagiarism.

Research question 1: Is there a significant difference between the Technical and Non-Technical programme students' act of plagiarism and frequency of plagiarism?

Table 2 presents the results of the TP and NTP students' act of plagiarism.

Table 2. Act of plagiarism by programme

\begin{tabular}{llll}
\hline & & Act of Plagiarism & \\
& & Yes & No \\
& No $\left(\%^{*}\right)$ & No $(\% *)$ \\
\hline \multirow{2}{*}{ Type of programme } & Technical $(n=60)$ & $43(71.7)$ & $17(28.3)$ \\
Total & Non-Technical $(n=60)$ & $33(55.0)$ & $27(45.0)$ \\
\hline
\end{tabular}

*Note: Percentage refers to percentage within programme.

We can see in Table 2 that plagiarism appears to be a common practice among the students in both programmes, particularly among the TP students $(71.7 \%$ students), however, the percentage of students who plagiarise did not differ significantly by programme, $\mathrm{X}^{2}(1, N=120)=3.59, p=.06$.

An examination of the frequency of plagiarism between the TP and NTP students, found that although the act of plagiarism is common among the students in both programmes, as seen in Table 3, it is not a habitual act. It appears to be an act that is either sometimes or, seldom practiced. 
Table 3. Frequency of plagiarism by programme

\begin{tabular}{llllll}
\hline & & \multicolumn{2}{l}{ Frequency of Plagiarism } & \\
& & Always & Sometimes & Seldom & Never \\
& & No $\left(\%^{*}\right)$ & No $\left(\%^{*}\right)$ & No $\left(\%^{*}\right)$ & No $\left(\%^{*}\right)$ \\
\hline $\begin{array}{l}\text { Type of } \\
\text { programme }\end{array}$ & Technical $(n=60)$ & $1(1.7)$ & $26(43.3)$ & $16(26.7)$ & $17(28.3)$ \\
Total $(n=120)$ & Non-Technical $(n=60)$ & $1(1.7)$ & $13(21.6)$ & $19(31.7)$ & $27(45.0)$ \\
\hline
\end{tabular}

*Note: Percentage refers to the percentage within the programme.

The sequence of frequencies of plagiarising, by the proportion of students for the $76(63.3 \%)$ students who reported they plagiarise, appears to be is sometimes (32.5\% students), followed by seldom ( $29.2 \%$ students) and only a very small proportion of students, i.e. less than 2 per cent reported they always plagiarise. In general, the NTP students appear to plagiarise less often, i.e. seldom (Seldom: $31.7 \%$ students) compared to the TP students (Seldom: $26.7 \%$ students). In fact, the number of TP students who plagiarise sometimes ( $43.3 \%$ students) is almost equal to the NTP students who do never plagiarise (45\% students). However, similar to the insignificant difference found in the act of plagiarising between the students in the two programmes, an insignificant relationship was also found between the frequency of plagiarism by programme, $\mathrm{X}^{2}(3, N=120)=6.9, p=.08$.

Research question 2: Is there a significant difference between male and female students' act of plagiarism and frequency of plagiarism by programme? As seen in Table 4, the act of plagiarism appears to be more prevalent among the male students ( $76.7 \%$ students) than the female students (50\% students), and the relationship between the act of plagiarism and gender was significant, $\mathrm{X}^{2}(1, N=120)=9.2, p=.00$.

Table 4. Act of plagiarism by gender and programme

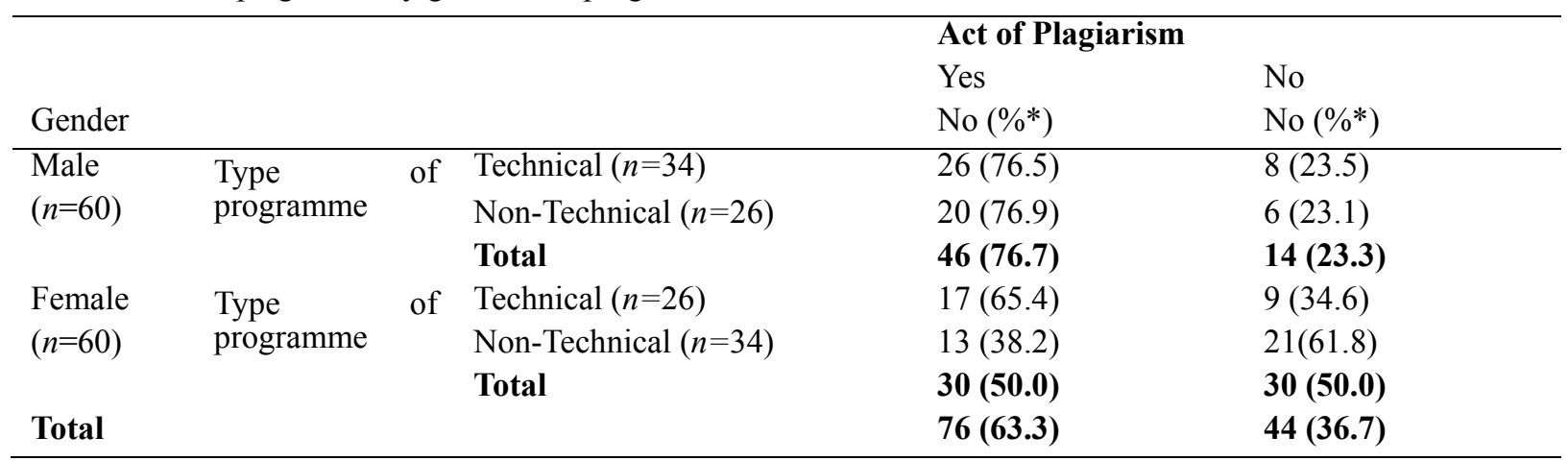

*Note: Percentage refers to percentage within type of programme.

When the act of plagiarism is compared by gender within programme, the difference in proportion of students who plagiarise among the male is lesser than the female students. Approximately 77 per cent of the male students in both programmes reported they plagiarise, however, the female TP students $(65.4 \%$ students $)$ appear to be more involved in the act of plagiarism compared to the NTP students (38.2 \% students), which conversely shows that a larger proportion of the female NTP students do not plagiarise. The difference in the proportion of students by genders and by programmes is not statistical significant among the males, but among the female students. Table 5 displays the results of the Pearson Chi-square test. 
Table 5. Pearson Chi-Square test results for the act of plagiarism by gender and programme

\begin{tabular}{lllll}
\hline Gender & & Value & df & Asymp. Sig (2 sided) \\
\hline Male & Pearson Chi-Square & .002 & 1 & .967 \\
Female & Pearson Chi-Square & 4.344 & 1 & .037 \\
Total & Pearson Chi-Square & 3.589 & 1 & .058 \\
\hline
\end{tabular}

A cross tabulation was also conducted to examine the frequency of plagiarism between genders in the two programmes. As seen in Table 4, the results presented in Table 6 show a similar pattern, with male students outnumbering the female students in their frequency of sometimes or seldom plagiarising (Male: $>60 \%$ students.; Female: $<40 \%$ students). As for the students who reported they do not plagiarise, the difference in the proportion of students by gender is not as obvious among the TP students compared to the NTP students, with a difference of approximately 50 per cent students.

Table 6. Frequency of plagiarism by gender and programme

\begin{tabular}{llll}
\hline \multirow{2}{*}{ Frequency of Plagiarism } & & $\begin{array}{l}\text { Type of Programme } \\
\text { Technical } \\
\text { No }\left(\%^{*}\right)\end{array}$ & $\begin{array}{l}\text { Non-Technical } \\
\text { No }\left(\%^{*}\right)\end{array}$ \\
\hline \multirow{2}{*}{ Always } & Male & $0(0.0)$ & $1(100.0)$ \\
& Female & $1(100.0)$ & $0(0.0)$ \\
Sometimes & Total & $\mathbf{1}(\mathbf{1 0 0 . 0})$ & $\mathbf{1 ( 1 0 0 . 0 )}$ \\
& Male & $16(61.5)$ & $8(61.5)$ \\
\multirow{3}{*}{ Seldom } & Female & $10(38.5)$ & $6(38.5)$ \\
& Total & $\mathbf{2 6 ( 1 0 0 . 0 )}$ & $\mathbf{1 3 ( 1 0 0 . 0 )}$ \\
& Male & $10(62.5)$ & $72(63.2)$ \\
Never & Female & $6(37.5)$ & $\mathbf{1 9}(\mathbf{1 0 0 . 0})$ \\
& Total & $\mathbf{1 6 ( 1 0 0 . 0 )}$ & $6(22.2)$ \\
& Male & $8(47.1)$ & $21(77.8)$ \\
& Female & $9(52.9)$ & $\mathbf{2 7}(\mathbf{1 0 0 . 0})$ \\
\hline
\end{tabular}

*Note: Percentage refers to percentage within frequency of plagiarism and type of programme.

An insignificant relationship was found between the frequency of plagiarism, gender and programme. Table 7 presents the Pearson Chi-Square results.

Table 7. Pearson Chi-Square test results for frequency of plagiarism by gender and programme

\begin{tabular}{lllll}
\hline Frequency of Plagiarism & & Value & df & Asymp. Sig (2 sided) \\
\hline Always & Pearson Chi-Square & 2.000 & 1 & .157 \\
Sometimes & Pearson Chi-Square & .212 & 1 & .645 \\
Seldom & Pearson Chi-Square & .002 & 1 & .968 \\
Never & Pearson Chi-Square & 2.966 & 1 & .085 \\
Total & Pearson Chi-Square & 2.133 & 3 & .144 \\
\hline
\end{tabular}

Research question 3: Is there a significant difference in the act of plagiarism and frequency of plagiarism among students in the different levels of study by programme? As mentioned earlier in the methodology section, the distribution of students per year of study was unequal, and therefore, to draw a more conclusive pattern, the act of plagiarism within each year of programme is compared. Reporting of data will exclude the Year 2 TP (no student) and Year 4 TP and NTP (small number of students in each programme) and therefore comparisons will be made between the Year 1 and Year 3 students, particularly in comparing the students' act of plagiarism by level of study. 
Table 8 . Act of plagiarism by level of study

\begin{tabular}{llllll}
\hline \multirow{2}{*}{ Act of Plagiarism } & \multicolumn{5}{c}{ Level of Study } \\
& Year 1 & Year 2 & Year 3 & Year 4 & Total \\
\cline { 2 - 6 } & No $(\% *)$ & No $(\%)$ & No $(\%)$ & No $(\%)$ & No (\%) \\
Yes & $31(81.6)$ & $13(68.4)$ & $29(50.0)$ & $3(60.0)$ & $\mathbf{7 6}(\mathbf{6 3 . 3})$ \\
Total & $7(18.4)$ & $6(31.6)$ & $29(50.0)$ & $2(40.0)$ & $\mathbf{4 4}(\mathbf{3 6 . 7 )}$ \\
\hline
\end{tabular}

*Note: Percentage refers to the percentage within level of study.

A visual inspection of Table 8 shows that the act of plagiarism is more prevalent among the juniors (Year 1) than the seniors (Years 2 and 3) and the inferential statistics of the Pearson Chi Square test found that the difference in the percentage of students is statistically significant, $\mathrm{X}^{2}(3, N=120)=10.0, p=.02$.

The descriptive statistics of the students' act of plagiarism by level of study and by programme is presented in Table 9, however, analysis of data will exclude the Year 2 TP students, since there were no students in this level.

Table 9. Plagiarism behaviour by year and programme

\begin{tabular}{|c|c|c|c|c|c|c|c|c|}
\hline \multicolumn{9}{|c|}{ Type of Programme } \\
\hline \multirow{3}{*}{$\begin{array}{ll}\text { Act } & \text { of } \\
\text { Plagiarism } & \end{array}$} & \multicolumn{4}{|l|}{ Technical } & \multicolumn{4}{|c|}{ Non-Technical } \\
\hline & Year 1 & Year 2 & Year 3 & Year 4 & Year 1 & Year 2 & Year 3 & Year 4 \\
\hline & No $(\% *)$ & No $(\% *)$ & No $(\% *)$ & No $(\% *)$ & No $(\% *)$ & No $(\% *)$ & No $(\% *)$ & No $(\% *)$ \\
\hline Yes $(n=76)$ & $24(80.0)$ & $0(0.0)$ & $18(66.7)$ & $1(33.3)$ & $7(87.5)$ & $13(68.4)$ & $11(35.5)$ & $2(100)$ \\
\hline No $(n=44)$ & $6(20.0)$ & $0(0.0)$ & $9(33.3)$ & $2(66.7)$ & $1(12.5)$ & $6(31.6)$ & $20(64.5)$ & $0(0.0)$ \\
\hline Total $(n=120)$ & $30(100)$ & $0(\mathbf{0 . 0})$ & $27(100)$ & $3(100)$ & $8(100)$ & $19(100)$ & $31(100)$ & $2(100)$ \\
\hline
\end{tabular}

*Note: Percentage refers to the percentage within year.

With a larger proportion of Year 1 students plagiarising, as seen in Table 8, it is not surprising to find a similar pattern when we compare the students' act of plagiarism by programme. We can see in Table 9 that more than 80 per cent of the Year 1 students in both programmes plagiarise compared to their seniors in Year 3. However, a wider difference in the proportion of students who plagiarise is found between the TP and NTP Year 3 students, i.e. the act of plagiarism prevails among the TP than than the NTP students (TP: $66.7 \%$ students; NTP: $35.5 \%$ students). Except or the Year 3 NTP students, a larger proportion of Year 1 and Year 3 TP students (approximately $60-80 \%$ students) reported they plagiarise The proportion of Year 3 NTP students who reported they do not plagiarise larger (64.5\% students). The Pearson Chi-Square test results presented in Table 10 shows that the difference in the percentage of students who are involved in the act of plagiarism by level of study and by programme, however, is statistically insignificant among the juniors in Year 1, but significant among the seniors in Year 3.

Table 10. Pearson Chi-Square test results for act of plagiarism by level of study and programme

\begin{tabular}{lllll}
\hline Level of study & & Value & $\mathrm{df}$ & Asymp. Sig (2 sided) \\
\hline Year 1 & Pearson Chi-Square & .236 & 1 & .627 \\
Year 2 & Pearson Chi-Square & & & \\
Year 3 & Pearson Chi-Square & 5.613 & 1 & .018 \\
Year 4 & Pearson Chi-Square & 2.222 & 1 & .136 \\
Total & Pearson Chi-Square & 3.878 & 1 & .049 \\
\hline
\end{tabular}

When the frequency of plagiarism was cross tabulated with the level of study, the results in Table 11 show that, except for the Year 3 NTP students, who outnumbered the TP students who never plagiarise (NTP: 69\% students; TP: $31 \%$ students), a larger proportion of Years 1 and 3 TP students reported they sometimes or seldom plagiarise 
compared to the Years 1 and 3 NTP students.

Table 11. Frequency of plagiarism by level of study and programme

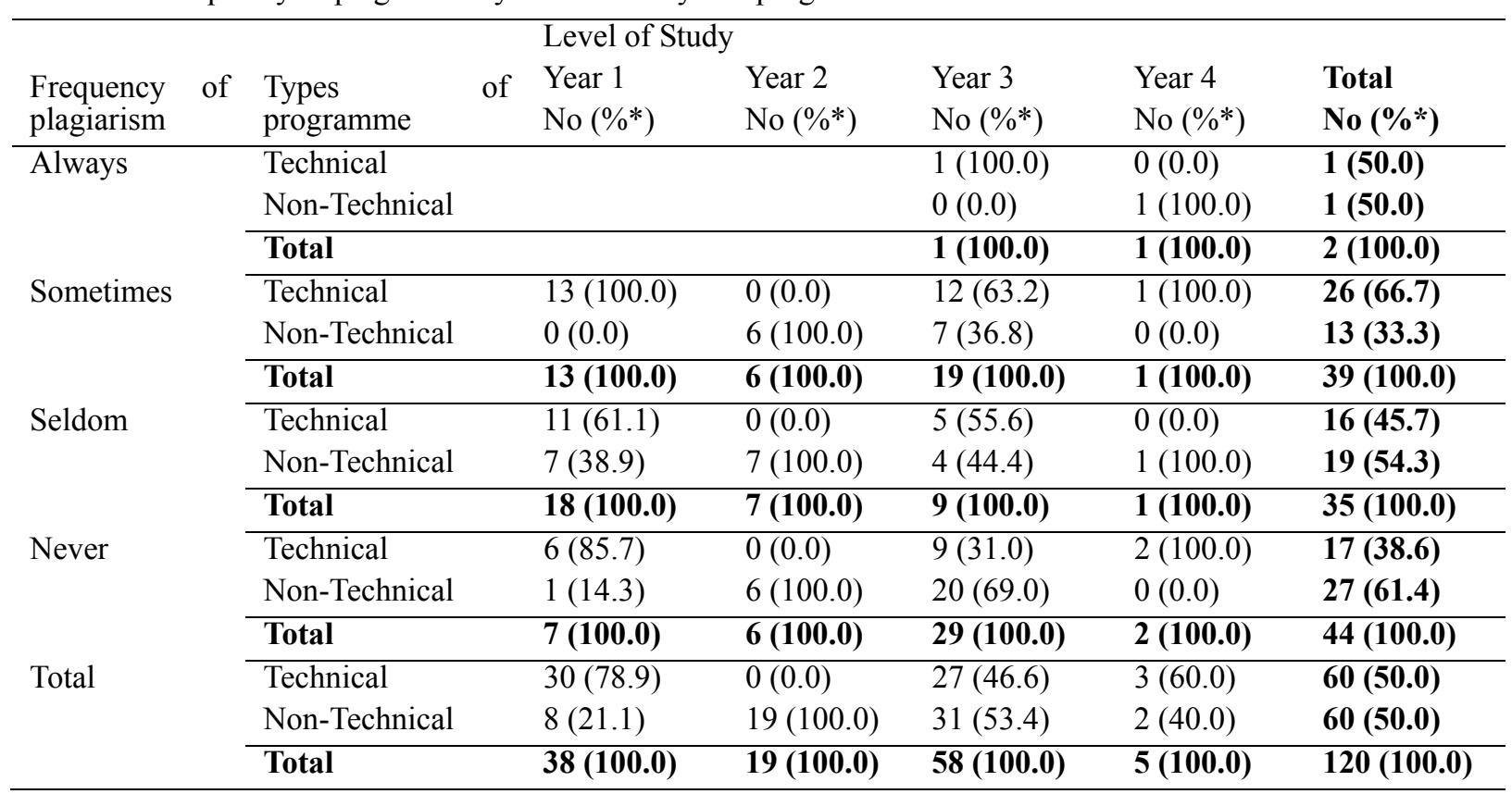

*Note: Percentage refers to percentage of frequency of plagiarism within level of study.

The inferential statistics presented in Table 12 shows that significant differences were found for never, seldom and sometimes, but not always plagiarise.

Table 12. Pearson Chi-Square test results for frequency of plagiarism by year and programme

\begin{tabular}{lllll}
\hline Frequency of plagiarism & & Value & df & Asymp. Sig (2 sided) \\
\hline Always & Pearson Chi-Square & 2.000 & 1 & .157 \\
Sometimes & Pearson Chi-Square & 19.105 & 3 & .000 \\
Seldom & Pearson Chi-Square & 8.808 & 3 & .032 \\
Never & Pearson Chi-Square & 14.205 & 3 & .003 \\
Total & Pearson Chi-Square & 32.213 & 3 & .000 \\
\hline
\end{tabular}

Research question 4: Is there a significant difference in the act of plagiarism and frequency of plagiarism among students of different academic achievement by programme? An examination of the act of plagiarism among students with different academic achievement, as presented in Table 13, found that average academic achievers tend to plagiarise compared to high achievers. The difference in the percentage of students who plagiarise is significant, $\mathrm{X}^{2}(4, N=120)=15.9, p=.00$. 
Table 13. Act of plagiarism by academic achievement

\begin{tabular}{llll}
\hline Academic & & \multicolumn{2}{l}{ Act of Plagiarism } \\
\cline { 3 - 4 } $\begin{array}{lll}\text { Achievement } \\
\text { Levels }\end{array}$ & GPA & Yes & No \\
\cline { 2 - 4 } Low & $<1.99$ & $0(0.0)$ & No $\left(\%^{*}\right)$ \\
Average & $2.0-2.49$ & $14(18.4)$ & $1(2.2)$ \\
High & $2.5-2.99$ & $30(39.5)$ & $5(11.4)$ \\
& $3.0-3.49$ & $23(30.3)$ & $5(11.4)$ \\
& $3.5-4.00$ & $9(11.8)$ & $22(50.0)$ \\
\hline
\end{tabular}

*Note: Percentage refers to the percentage within act of plagiarism.

As seen in Table 14, a further examination of the TP and NTP students' act of plagiarism in relation to their academic achievement found that all, except the one student with a low GPA, reported they plagiarise.

Table 14. Act of plagiarism by academic achievement and programme

\begin{tabular}{|c|c|c|c|c|c|}
\hline \multirow{3}{*}{$\begin{array}{l}\text { Act of } \\
\text { Plagiarism }\end{array}$} & \multirow{3}{*}{$\begin{array}{l}\text { Academic } \\
\text { Achievement } \\
\text { Levels }\end{array}$} & \multirow{3}{*}{ GPA } & \multicolumn{2}{|c|}{ Type of Programme } & \multirow{3}{*}{ Total } \\
\hline & & & Technical & Non-Technical & \\
\hline & & & & & \\
\hline \multirow{6}{*}{ Yes } & \multirow{2}{*}{ Average } & $2.0-2.49$ & $12(27.9)$ & $2(6.1)$ & $14(18.4)$ \\
\hline & & $2.5-2.99$ & $11(25.6)$ & $19(57.6)$ & 30 (39.5) \\
\hline & \multirow{3}{*}{ High } & $3.0-3.49$ & $14(32.6)$ & $9(27.3)$ & $23(30.3)$ \\
\hline & & $3.5-4.00$ & $6(14.0)$ & $3(9.0)$ & 9 (11.8) \\
\hline & & Total & $43(100)$ & $33(100)$ & $76(100)$ \\
\hline & Low & $<1.99$ & $1(5.9)$ & $0(0.0)$ & $1(2.3)$ \\
\hline \multirow{4}{*}{ No } & \multirow{2}{*}{ Average } & $2.0-2.49$ & $4(23.5)$ & $1(3.7)$ & $5(11.4)$ \\
\hline & & $2.5-2.99$ & $3(17.6)$ & $2(7.4)$ & $5(11.4)$ \\
\hline & \multirow[t]{2}{*}{ High } & $3.0-3.49$ & $\begin{array}{l}7(41.2) \\
2(11.7)\end{array}$ & $\begin{array}{l}15(55.6) \\
9(33.3)\end{array}$ & $\begin{array}{l}22(50.0) \\
11(25.0)\end{array}$ \\
\hline & & Total & 17 (100) & $27(100)$ & $44(100)$ \\
\hline \multirow{6}{*}{ Total } & Low & $<1.99$ & $1(1.7)$ & $0(0.0)$ & $1(0.8)$ \\
\hline & \multirow{2}{*}{ Average } & $2.0-2.49$ & $16(26.7)$ & $3(5.0)$ & $19(15.8)$ \\
\hline & & $2.5-2.99$ & $14(23.3)$ & $21(35.0)$ & $35(29.2)$ \\
\hline & \multirow{3}{*}{ High } & $3.0-3.49$ & $21(35.0)$ & $24(40.0)$ & $45(37.5)$ \\
\hline & & $3.5-4.00$ & $8(13.3)$ & $12(20.0)$ & $20(16.7)$ \\
\hline & & Total & $60(100)$ & $60(100)$ & $120(100)$ \\
\hline
\end{tabular}

Note: Percentage refers to the percentage within programme.

A similar pattern of plagiarism being more prevalent among the average achievers is found among only the NTP, but not the TP students. The average NTP achievers outnumbered the high achievers (Average achievers: 63.6\% students; High achievers: $36.4 \%$ students). In contrast to the difference in the proportion of students, which is found to be not obvious among the TP students who plagiarise, it is on the contrary to the students who reported they do not plagiarise; the high achievers who do plagairise outnumbered the average achievers within the NTP group (High achievers: 88.9 students; Average achievers: 11.1\% students). The inferential statistics of the Pearson Chi-Square test results in Table 15 show that the difference between the TP and NTP students, in relation to their GPA did not differ among the average achievers, but among the high achievers (GPA of $>3.00$ ). 
Table 15. Pearson Chi-Square test results for the act of plagiarism in relation to the GPA

\begin{tabular}{lllll}
\hline GPA & & Value & df & Asymp. Sig (2 sided) \\
\hline$<1.99$ & Pearson Chi-Square & & & \\
$2.0-2.49$ & Pearson Chi-Square & .090 & 1 & .764 \\
$2.5-2.99$ & Pearson Chi-Square & .972 & 1 & .324 \\
$3.0-3.49$ & Pearson Chi-Square & 3.813 & 1 & .050 \\
$3.5-4.0$ & Pearson Chi-Square & 4.848 & 1 & .028 \\
\hline
\end{tabular}

The results of the frequency of plagiarism in relation to GPA presented in Table 16 show that the high achievers reported they plagiarise less frequently compared to the average achievers.

Table 16. Frequency of plagiarism in relation to the academic achievement

\begin{tabular}{|c|c|c|c|c|}
\hline \multirow{3}{*}{$\begin{array}{l}\text { Frequency of } \\
\text { Plagiarism }\end{array}$} & \multirow{3}{*}{$\begin{array}{l}\text { Academic } \\
\text { Achievement } \\
\text { Levels }\end{array}$} & \multirow[b]{3}{*}{ GPA } & \multicolumn{2}{|c|}{ Type of Programme } \\
\hline & & & Technical & Non-Technical \\
\hline & & & No $(\% *)$ & No $(\% *)$ \\
\hline \multirow{6}{*}{ Always } & Low & $<1.99$ & $0(0.0)$ & $0(0.0)$ \\
\hline & \multirow{2}{*}{ Average } & $2.0-2.49$ & $0(0.0)$ & $0(0.0)$ \\
\hline & & $2.5-2.99$ & $1(100)$ & $0(0.0)$ \\
\hline & \multirow{3}{*}{ High } & $3.0-3.49$ & $0(0.0)$ & $0(0.0)$ \\
\hline & & $3.5-4.00$ & $0(0.0)$ & $0(100)$ \\
\hline & & Total & $1(100)$ & $1(100)$ \\
\hline \multirow{6}{*}{ Sometimes } & Low & $<1.99$ & $0(0.0)$ & $0(0.0)$ \\
\hline & \multirow{2}{*}{ Average } & $2.0-2.49$ & $8(30.8)$ & $0(0.0)$ \\
\hline & & $2.5-2.99$ & $6(23.1)$ & $11(84.6)$ \\
\hline & \multirow{2}{*}{ High } & $3.0-3.49$ & $10(38.5)$ & $1(7.7)$ \\
\hline & & $3.5-4.00$ & $2(7.7)$ & $1(7.7)$ \\
\hline & & Total & $26(100)$ & $13(100)$ \\
\hline \multirow{6}{*}{ Seldom } & Low & $<1.99$ & $0(0.0)$ & $0(0.0)$ \\
\hline & \multirow{2}{*}{ Average } & $2.0-2.49$ & $4(25)$ & $2(10.5)$ \\
\hline & & $2.5-2.99$ & $4(25)$ & $8(42.1)$ \\
\hline & \multirow{3}{*}{ High } & $3.0-3.49$ & $4(25)$ & $8(42.1)$ \\
\hline & & $3.5-4.00$ & $4(25)$ & $1(5.3)$ \\
\hline & & Total & $16(100)$ & $19(100)$ \\
\hline \multirow{6}{*}{ Never } & Low & $<1.99$ & $1(5.9)$ & $0(0.0)$ \\
\hline & \multirow{2}{*}{ Average } & $2.0-2.49$ & $4(23.5)$ & $1(3.7)$ \\
\hline & & $2.5-2.99$ & $3(17.6)$ & $2(7.4)$ \\
\hline & \multirow{3}{*}{ High } & $3.0-3.49$ & $7(41.2)$ & $15(55.6)$ \\
\hline & & $3.5-4.00$ & $2(11.8)$ & $9(33.3)$ \\
\hline & & Total & $17(100)$ & $27(100)$ \\
\hline \multirow{6}{*}{ Total } & Low & $<1.99$ & $1(1.7)$ & $0(0.0)$ \\
\hline & \multirow{2}{*}{ Average } & $2.0-2.49$ & $16(26.7)$ & $3(5.0)$ \\
\hline & & $2.5-2.99$ & $14(23.3)$ & $21(60.0)$ \\
\hline & \multirow{3}{*}{ High } & $3.0-3.49$ & $21(35.0)$ & $24(40.0)$ \\
\hline & & $3.5-4.00$ & $8(13.3)$ & $12(20.0)$ \\
\hline & & Total & $60(100)$ & $60(100)$ \\
\hline
\end{tabular}

*Note: Percentage refers to percentage within programme.

In general, within each programme, there is no obvious difference in the proportion of average and high achievers who reported they sometimes or seldom plagiarise, except among the NTP students who noted they sometimes plagarise. This is more obvious among the NTP students (Average GPA: 84.6\% students; High GPA: 
15.4\% students) than the TP students (Average GPA: 53.7\% students; High GPA: 46.3\% students). However, in both programmes, the high achievers outnumbered the average achievers: High achievers: NTP $(88.9 \%$ students), TP (52.9\% students); Average achievers: NTP (11.1\% students), TP (47.1\% students). As for the students who reported they seldom plagiarise, the difference in the proportion of students is minimal within each programme and therefore, it is not surprising to find insignificant differences in the various frequency scales except plagiarising sometimes. The Pearson Chi-Square test results are presented in Table 17.

Table 17. Pearson Chi-Square test results for frequency of plagiarism in relation to their GPA

\begin{tabular}{lllll}
\hline CGPA & & Value & df & Asymp. Sig (2 sided) \\
\hline Always & Pearson Chi-Square & 2.000 & 1 & .157 \\
Sometimes & Pearson Chi-Square & 14.439 & 3 & .002 \\
Seldom & Pearson Chi-Square & 4.912 & 3 & .178 \\
Never & Pearson Chi-Square & 8.532 & 4 & .074 \\
\hline Total & Pearson Chi-Square & 12.295 & 4 & .015 \\
\hline
\end{tabular}

\section{Discussion and Conclusion}

Discussion on the findings of this study is presented in answer to the research questions. To recap, the aim of this study was to examine the TP and NTP students' plagiarism behaviour and frequency of plagiarism.

The first research question addressed the TP and NTP student's act and frequency of plagiarism. What was obvious in this study was that the act of plagarising appears to be prevalent in the two programmes and albeit the difference was insignificant, the number of TP students who reported they plagiarise outnumbered the NTP students. This result appears to be consistent with Harding et al. (2001), Newstead et al. (1996) and, McCollough and Holmberg's (2005) findings, but contradicts Brown, Weible and Olmosk (2010), Caruana et al. (2000), Harris (1989), Smyth and Davis (2004) and Park (2003). However, it ought to be noted that the students who reported they plagiarised also reported that it was not habitual, rather it was a 'sometimes' or 'seldom' behaviour, which could be due to the academic load or the nature of the programme. On the frequency scale, a significant difference was found among the students who seldom and never plagiarise.

The second research question addressed the act and frequency of plagiarism between genders in the two programmes. This study found that although no significant difference was found in the act of plagiarism among the students in the two programmes, a significant difference, however, was found between the male and female students, which contradicts Roig and Caso (2005) Bilic-Zulle, et al. (2005) who concluded that plagiarism rate is not significantly affected by gender. The findings also contradict Taylor Bianco and Deeter Schmelz (2007), and Mirshekary and Lawrence (2009) who found that female students were more likely to plagiarise. Consistent with Hendershott, Drinan and Cross (1999), McCabe \& Treviño (1997), Rocha and Teixeira (2005a, b), Simon et al. (2004) Straw (2002) and Yang's (2014) findings, the act of plagiarising appears to be more prevalent among the males than females in this study. A further cross examination of the act of plagiarism by gender and programme, however, found that a significant difference was found only among the NTP female students. The difference in the percentage of students who plagiarise at different frequencies by gender was also not significant.

The third research question was aimed at examining the plagiarism behaviours of students by seniority. It ought to be noted that since the distribution of the student number per year of programme was unequal, we are unable to draw a conclusive pattern of the students' plagiarism behaviour within each year of the programmes. In addition, for the purpose of discussion, Years 2 (no students) and 4 (1 student) of the TP students and Year 4 (1 student) of the NPT students were excluded due to the small group size. However, this study found an association between seniority and the act of plagiarism. The act of plagiarism was more prevalent among the juniors in Year 1 in both programmes than their seniors. Acknowledging the inconclusiveness of the result, it appears to be consistent with Rocha and Teixiera (2005a), and Rinnert and Kobayahi (2005), who also reported similar findings, i.e. junior students are more likely to plagiarise compared to their seniors. A possible reason could be that they are more aware of the consequences or as they progress in their year of studies, their quoting, citing and paraphrasing skills could have improved. Interestingly, a comparison the Year 3 TP and NTP students' act of found that the senior NTP students, i.e. in the non-science disciplines were less likely to plagiarise compared to the TP students in the science discipline. The inferential data showed that the difference in the 
percentage of students between the programme was statistically significant. Similarly, a statistically significant difference was found among the students who sometimes or seldom plagiarise.

In addressing the final research question on the act and frequency of plagiarism in relation to the students' academic performance, it was evident that the high achievers were less likely to plagiarise compared to the average achievers. This finding is consistent with the findings of Deckert (1993), McCabe and Trevino (1997) Sims (1995), Smith et al. (2002), Smyth, Davis and Kroncke (2009), and Rinnert and Kobayahi (2005). The results also showed that high NTP achievers tend to plagiarise less frequently than the TP students, however, on the frequency scale, this study found significant differences in the proportion of students who sometimes plagiarise.

In general, this study clearly points to the fact that the act of plagiarism, albeit 'sometimes or seldom' is common among the students in both programmes, it is pervasive among the TP than the NTP students. Thus, both the faculty members and the university will need to address it before it becomes an act that is always conducted among all students. With a considerable number of students who do not plagiarise, taking heed to this findings and acting immediately to address intellectual theft before it becomes widespread is imperative. It is paramount that the faculty members and the university raise awareness of the consequences of plagiarism among students and take actions against perpetrators of intellectual rights.

\section{Reference}

Baird, J. S., Jr. (1980). Current trends in college cheating. Psychology in the Schools, 17, 515-522. http://dx.doi.org/10.1002/1520-6807(198010)17:4<515::AID-PITS2310170417>3.0.CO;2-3.

Bilic-Zulle, L., Frkovic, V., Turk, T., Azman, J., \& Petrovecki, M. (2005). Prevalence of plagiarism among medical students. Croat Med J., 46(1), 126-131.

Bisping, T., Patron, H., \& Roskelley, K. (2008). Modeling academic dishonesty: The role of student perceptions and misconduct type. Journal of Economic Education, 39(1), 4-21. http://dx.doi.org/10.3200/JECE.39.1.4-21.

Burton, J. H., Talpade, S., \& Haynes, J. (2011). Religiosity and test-taking ethics among Business School Students. Journal of Academic and Business Ethics, 4, 1-8.

Bushway, A., \& Nash, W. R. (1977). School cheating behavior. Review of Educational Research, 47, 623-632. http://dx.doi.org/10.3102/00346543047004623

Caron, M. D., Whitbourne, S. K., \& Halgin, R. P. (1992). Fraudulent excuse making among college students. Teaching of Psychology, 19(2), 90-93. http://dx.doi.org/10.1207/s15328023top1902_6

Carroll, J. (2002). A handbook for deterring plagiarism in higher education. Oxford: Oxford Centre for Staff and Learning Development.

Caruana, A., Ramaseshan, B., \& Ewing, M. T. (2000). The effect of anomie on academic dishonesty among university students. International Journal of Educational Management, 14(1), 23-30. http://dx.doi.org/10.1108/09513540010310378

Dekert, G. D. (1993). Perspectives on plagiarism from ESL students in Hong Kong, Journal of Second Language Writing, 2(2), 131-148. http://dx.doi.org/10.1016/1060-3743(93)90014-t

Groark, M., Oblinger, D., \& Choa, M. (2001). Term paper mills, anti-plagiarism tools, and academic integrity, Educause Review, 36(5), 40-48.

Clement, M. J. (2001). Academic dishonesty: To be or not to be? Journal of Criminal Justice. http://dx.doi.org/10.1080/10511250100086101

Hadjiah, I., Norashikin, H., Nusrah, S., Fauziah, N., \& Normala, D. (2013). Academic Dishonesty: Why Business Students Participate in These Practices? Social and Behavioral Sciences, 90, 152-156. http://dx.doi.org/10.1016/j.sbspro.2013.07.076

Haines, V. J., Diekhoff, G. M., LaBeff, E. E., \& Clark, R. E. (1986). College cheating: Immaturity, lack of commitment, and the neutralizing attitude. Research in Higher Education, 25(4), 342-354. http://dx.doi.org/10.1007/BF00992130

Harding, S. T., Carpenter, D. D., Montgomery, S. M. \& Stenech, N. H. (2001). The current state of research on academic dishonesty among Engineering students. Paper presented at. the 31st ASEE/IEEE Frontiers in Education Conference Reno, NV. http://dx.doi.org/10.1109/fie.2001.963948 
Harris, J. R. (1989). Ethical values and decision processes of male and female business students. Journal of Education for Business, 64(5), 234-8. http://dx.doi.org/10.1080/08832323.1989.10117365

Hendershott, A., Drinan, P. F., \& Cross, M. (1999). Gender and academic integrity. Journal of College Student Development, 40, 345-354.

Lehman, C. M., \& DuFrene, D. (2011). Business communication (16th ed.). Mason, OH: South-Western/Cengage Learning

Lin, C. H. S., \& Wen, L.Y. M. (2007). Academic dishonesty in higher education: A nationwide study in Taiwan. Higher Education, 54(1), 85-97. http://dx.doi.org/10.1080/1360080X.2015.1102823

Newstead, S., Franklyn-Stokes, A., \& Armstead, P. (1996). Individual differences in student cheating. Journal of Educational Psychology, 88(2), 229-241. http://dx.doi.org/10.1037/0022-0663.88.2.229

McCabe, D. L., \& Trevino, L. K. (1997). Individual and contextual influences on academic dishonesty: A multicampus investigation. Research in Higher Education, 38(3), 379-396. http://dx.doi.org/10.1023/A:1024954224675

McCabe, D. L., Trevino, L. K., \& Butterfield, K. D. (2001). Dishonesty in academic environments. Journal of Higher Education, 72(1), 29-45. http://dx.doi.org/10.2307/2649132

McCullough, M., \& Holmberg, M. (2005). Using the Google search engine to detect word-for-word plagiarism in Master's theses: A preliminary study. College Student Journal, 39(3), 435-441.

Mohd, I. M., Salleh, Noor R., Alias, H. A., \& Hamid, Z. Y. (2013). Academic dishonesty among undergraduates in the higher education. International Journal of Academic Research, 5(2), 222-227. http://dx.doi.org/10.7813/2075-4124.2013/5-2/B.34

Mirshekary S., \& Lawrence, A. D. K. (2009). Academic and business ethical misconduct and cultural values: a cross national comparison. Academic Ethics, 7, 141-157. http://dx.doi.org/10.1007/s10805-009-9093-0

Oliphant, T. (2002). Cyber-plagiarism: plagiarism in a digital world. Feliciter, 48(2), 78-80.

Paldy, L. G. (1996) The problem that won't go away: addressing the causes of cheating. Journal of College Science Teaching, 26(1), 4-6.

Park, C. (2003). In other (people.s) words: Plagiarism by university students-literature and lessons. Assessment and Evaluation in Higher Education, 28(5), 471.488.

Rinnert, C., \& Kobayashi, H. (2005). Borrowing words and ideas: Insight from Japanese L1 writers. Journal of Asian Pacific Communication, 15(1), 31-56. http://dx.doi.org/10.1075/japc.15.1.04sut

Rocha, M. F., \& Teixeira, A. A. C. (2005a). Crime without punishment: An update review of the determinants of cheating among university students. no. 191, October 2005.

Rocha, M. F., \& Teixeira, A. A. C. (2005b). College cheating in Portugal: Results from a large scale survey. FEP working papers no. 197, Dec 2005.

Roig M., \& Caso M. (2005). Lying and cheating: fraudulent excuse making, cheating, and plagiarism. The Journal of Psychology, 139(6), 485-494. http://dx.doi.org/10.3200/JRLP.139.6.485-494

Sierles, F., Hendrickx, I., \& Circle, S. (1980). Cheating in medical school. Journal of Medical Education, 55(2), 124-125. http://dx.doi.org/10.1097/00001888-198002000-00006

Simon, C. A., Carr, J. R., McCullough, S. M., Morgan, S. J., Oleson, T., \& Ressel, M. (2004). Gender, student perceptions, institutional commitments and academic dishonesty: Who reports in academic dishonesty cases? Assessment $\&$ Evaluation in Higher Education, 29(1), 75-90. http://dx.doi.org/10.1080/0260293032000158171

Sims, R. L. (1995). The severity of academic dishonesty: A comparison of faculty and student views. Psychology in the Schools, 233-238. http://dx.doi.org/10.1002/1520-6807(199507)32:3<233::AID-PITS2310320311>3.0.CO;2-H

Smyth, L. S., Davis, J. R., \& Kroncke, C. O. (2009). Students' perceptions of business ethics: Using cheating as a surrogate for business situations. Journal of Education for Business, 84(4), 229-239. http://dx.doi.org/10.3200/JOEB.84.4.229-239

Smith, K. J., Davy, J. A., Rosenberg, D. L., \& Haight, G. T. (2002). A structural modeling investigation of the influence of demographic and attitudinal factors and in-class deterrents on cheating behaviors among 
accounting majors. Journal of Accounting Education, 20(1), 45-65. http://dx.doi.org/10.1016/S0748-5751(01)00026-4

Smith, M., Ghazali N., \& Noor Minhad, S. F. (2007). Attitudes towards plagiarism among undergraduate accounting students: Malaysian evidence. Asian Review of Accounting, 15(2), 122-146 http://dx.doi.org/10.1108/13217340710823350

Smyth, M. L., \& Davis, J. R. (2004). Perception of dishonesty among two-years college students: Academic versus business situation. Journal of Business Ethics, 51(1), 63-73. http://dx.doi.org/10.1023/B:BUSI.0000032347.79241.3c.

Stebelman, S. (1998). Cybercheating: dishonesty goes digital. American Libraries, 29(8), 48-51.

Straw, D. (2002). The plagiarism of generation 'why not?' Community College Week, 14(24), 4-7.

Taylor-Bianco, A., \& Deeter-Schmelz, D. (2007). An exploration of gender and cultural differences in MBA students' cheating behavior: Implications for the classroom. Journal of Teaching in International Business, 18(4), 81-99. http://dx.doi.org/10.1300/J066v18n04_05

Ting, S. H., (2013, June, 4-5). Academic writing: Citation is troublesome and plagiarism is no big deal. Paper presented at International Conference on Social Science Research, Penang. Malaysia. Retrieved from http://ir.unimas.my/717/1/Academic\%2Bwriting\%2Bcitation\%2B\%2528abstract\%2529.pdf.

Thompson, S. (2003). Why do students plagiarize? Retrieved from http://library.csusm.edu/plagiarism/howtocredit/how_credit_online.htm

Yang, W. (2014). A quantitative study of ESL/EFL students' understanding of plagiarism, (Master's thesis, Indiana University of Pennsylvania, Pennsylvania, United States). Retrieved from http://dspace.iup.edu/bitstream/handle/2069/2228/Wenxi\%20Yang\%20(Thesis).pdf?sequence=1.

Wilson, R. (1999). Colleges urged to better define academic integrity and to stress its importance. Chronicle of Higher Education, 46(8), A18.

\section{Copyrights}

Copyright for this article is retained by the author(s), with first publication rights granted to the journal.

This is an open-access article distributed under the terms and conditions of the Creative Commons Attribution license (http://creativecommons.org/licenses/by/3.0/). 